\title{
College Events
}

\section{Newborn week Celebration Nov, 2016}

\section{In commemoration \\ of New born week,} Department of Child Health Nursing, KGNC organized a series of activities from 15th -21st Nov 2016. Poem writing competition on the theme 'New Born' and posters on the theme 'New Born care'. A healthy baby contest was conducted and Children were evaluated

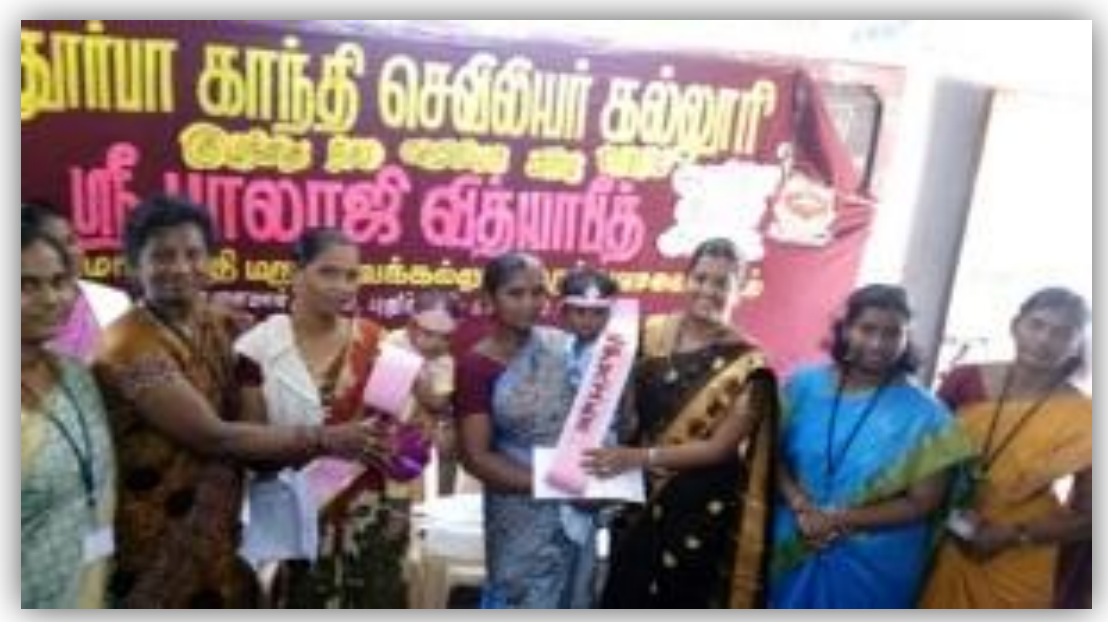
based on a structured evaluation proforma and children were awarded with gifts . Interactive session was organized by M.Sc. Nursing I year, Dept. of Child Health Nursing on the theme of new born care at post natal ward of MGMCRI .

\section{World AIDS Awareness Week 2016Dec, 2016}

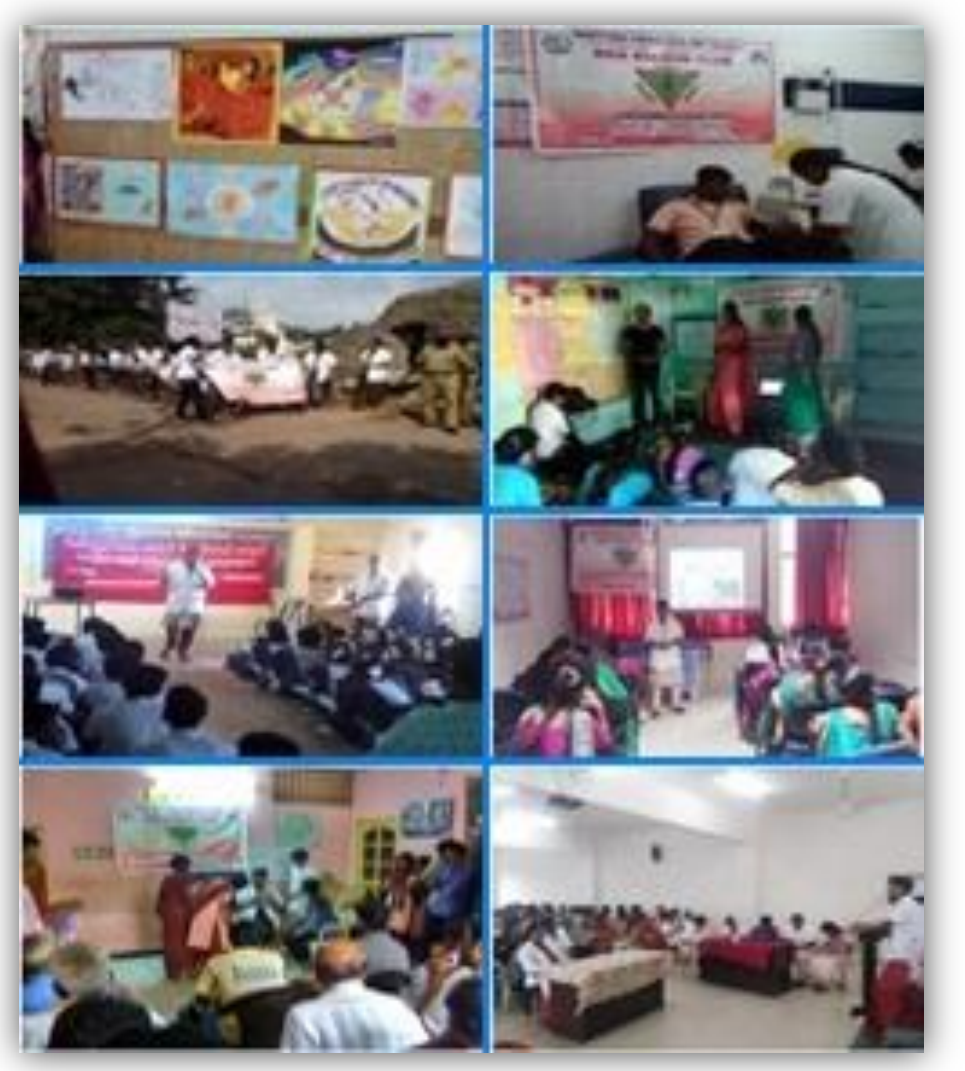

Red Ribbon Club of KGNC Commemorated World AIDS Awareness Week 2016 from 1.12.2016to 09.12.2016 by conducting various Programs, on 1.12.2016,RRC of KGNC in collaboration with Department of Community Medicine, MGMCRI conducted Poster competition, Slogan writing and Short video message. A Voluntary Blood Donation Camp was conducted on 2.12.2016 at Blood Bank, MGMCRI. A Public awareness program - Bicycle Rally on HIV/AIDS Awareness was conducted by 45 volunteer's students from B.Sc (N) I, III \& IV year at MGMCRI- MGMCRI (Through Kirumampakkam, Manapet, Narambai, 
Mullodai and Kanniyakovil). A Health talk for Transgender regarding Prevention of Venereal diseases on 4.12.2016 at SCHOD Society, Cuddalore. A video show and Interaction session for Antenatal mothers on Prevention of HIV through Parent- Child Transmission at Antenatal OPD, MGMCRI on 5.12.2016 and Lucky Draw Programme on AIDS Awareness for the 11thstd School Students from Dr. Ambedkar. Govt. Hr. Sec. School, Pudupalayam. On 7.12.16 a Skit titled 'Exploring the relationship between HIV/AIDS and Alcoholism' in Bharat Matha De- Addiction Centre, Ariyankuppam. A debate on the topic of "Media and Family Influence on Present Day Adolescents - Are they positive or negative towards prevention of HIV/AIDS?" was organized on 09.12.2016 at KGNC .The Session was moderated by Prof. Ambujam, Dept.of. DVL, MGMCRI. End of the Debate session, the Valediction Programme was conducted. All the winners and participants were issued certificates by the chief guest. Overall the programmes ended with grand success.

\section{Scientific Academic Forum Jan \& Feb 2017}

Department of Medical Surgical Nursing hosted the Scientific Academic Forum on 10.1.17. The objective of the forum was to throw light on Critical Care Nursing. The B.Sc (N) Student's brains were conjured up by the Quiz Time which was a good drill and thrill for the students. The shovel of the forum was the

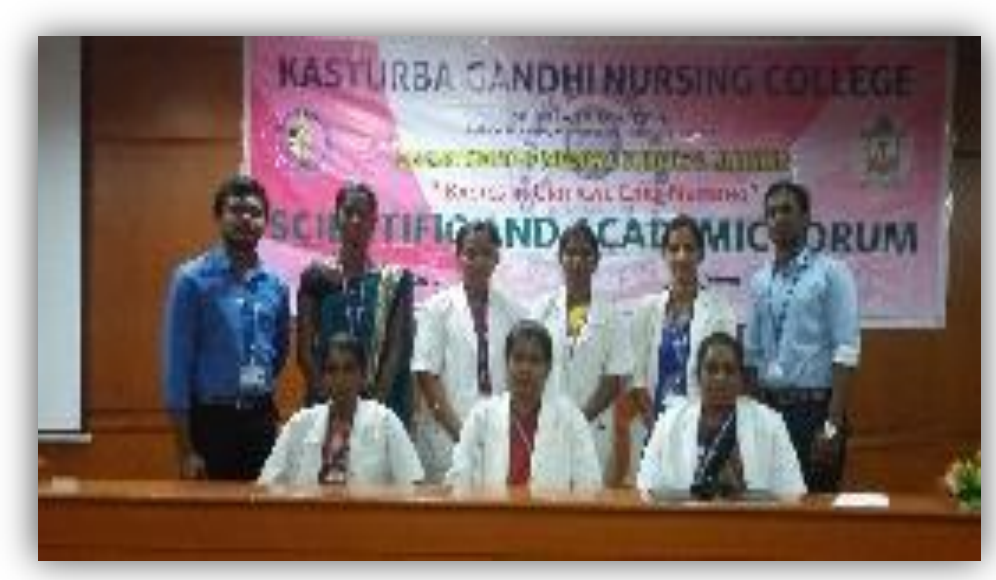
talk on FAST HUG - Care Of Patients In Critical Care Nursing by Dr. Alai Taggu HOD, Critical Care Medicine, MGMCRI which was very informative for the students. At the end of the programme, feedback was obtained and it was graded as Excellent

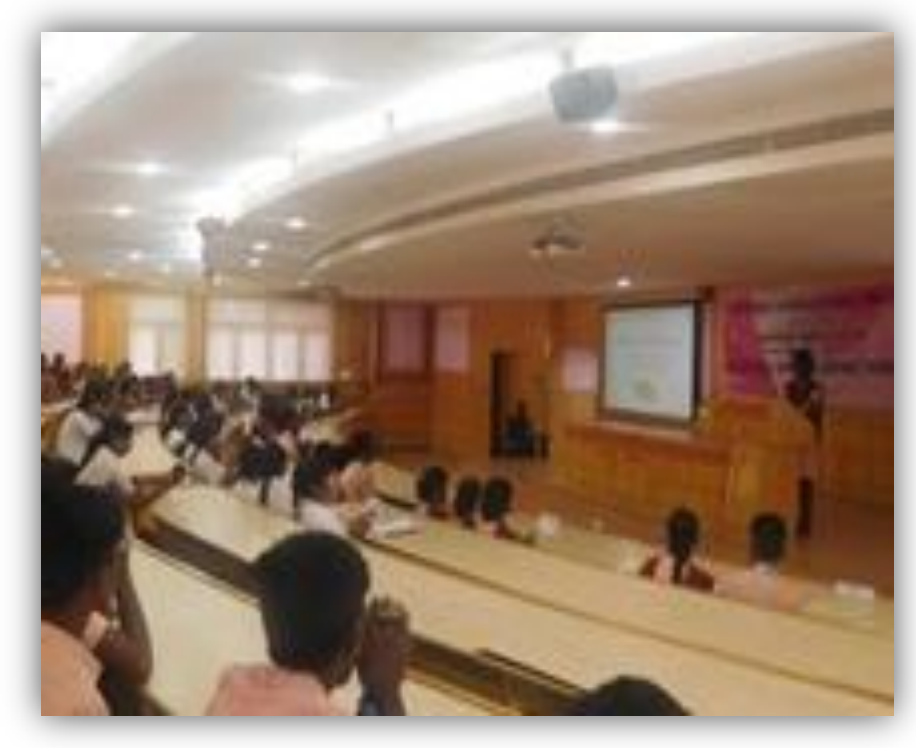

Dept of Nursing Foundation organized Scientific Academic Forum on the theme "Nurses lead in fighting Infection" on 28.2.17. Quiz competition was conducted for the B.Sc (N) I year students on the theme. Dr. Kalaivani .R ,Asso.Prof, Dept. of. Microbiology, MGMCRI, was the Guest speaker who threw light on "Fighting Infection "which caught the attention of the students. The programme came to an end with the vote of thanks. 


\section{Nursing Education Unit - CM\&SHPS Feb, 2017}

Nursing Education Unit \& Internal Quality Assurance Cell Jointly Organized a guest lecture on "Classroom Management \& Strategies to Handle Problem Students" on 01.02.2017 at I Floor, MEU, MGMCRI.TheGuestSpeaker Dr. R. Muthumanickam, Principal, Krishnasamy

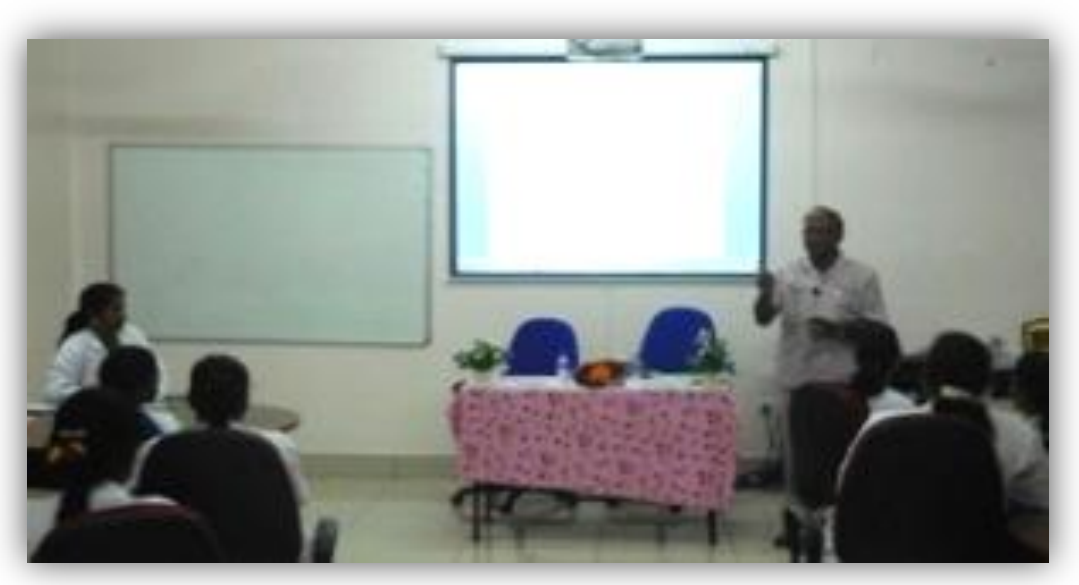

College of Education for Women, Puducherry, the chief guest of the day deliberated on the classroom management strategies. The lecture strengthened the effective way of handling students more simply, passionately and with an attitude of indifference thereby improving our classroom management effectiveness. There was also a brief group discussion at the end of the session. The guest speaker was honored with memento.

\section{COMMUNICATION BUILDING PROGRAMME Feb, 2017}

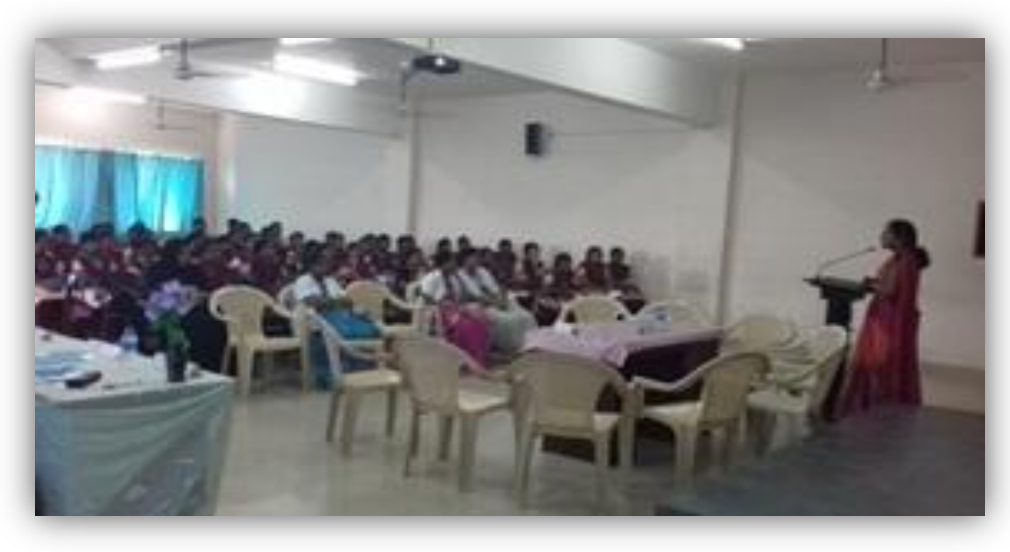

Dept. of Nursing Foundation for the B.Sc $(\mathrm{N})$ I year on 15.02.2017 focusing on the theme "Preparing Young Orators - Reflection on communication Building .The dignitaries on the Dias was Dr.Renuka.K,Principal of KGNC, Ms. Liza D'Cruz,

Language Expert ,T.S.Words ,Puducherry . Mrs. Josphine.M.B, Sr. Student Welfare Officer, SBV, Mr.Stephen Raj,Language Trainer, T.S.Words, Mr.Victor Paschal, Language Trainer in Hospitality Industry. As a part of reflection of communication skill Building, various competitions like Podium presentation, Just A Minute \& Debate were conducted for the students. Students enthusiastically participated in the contest.

\section{MATRIBHASHA DIWAS Feb, 2017}

Matribhasha Diwas - 2017, with "International Mother Language Day"as the theme of the year, was commemorated in KGNC on 22.02.17. An essay competition 
on 'Keeping Alive - the Mother Tongue' (English \& Tamil) \& Magic of Multilingualism (English) was conducted at Ground Floor, KGNC, Puducherry. The day had a good number of PG \& UG student participations.

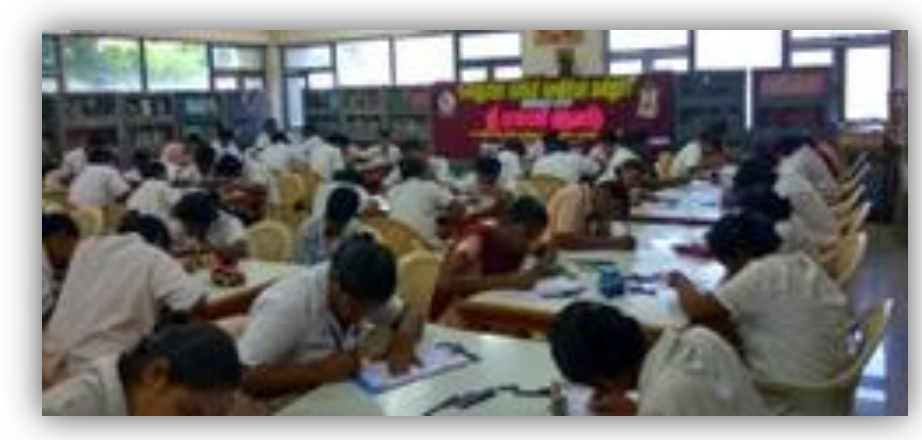

\section{NATIONAL BURNS AWARENESS WEEK Feb, 2017}

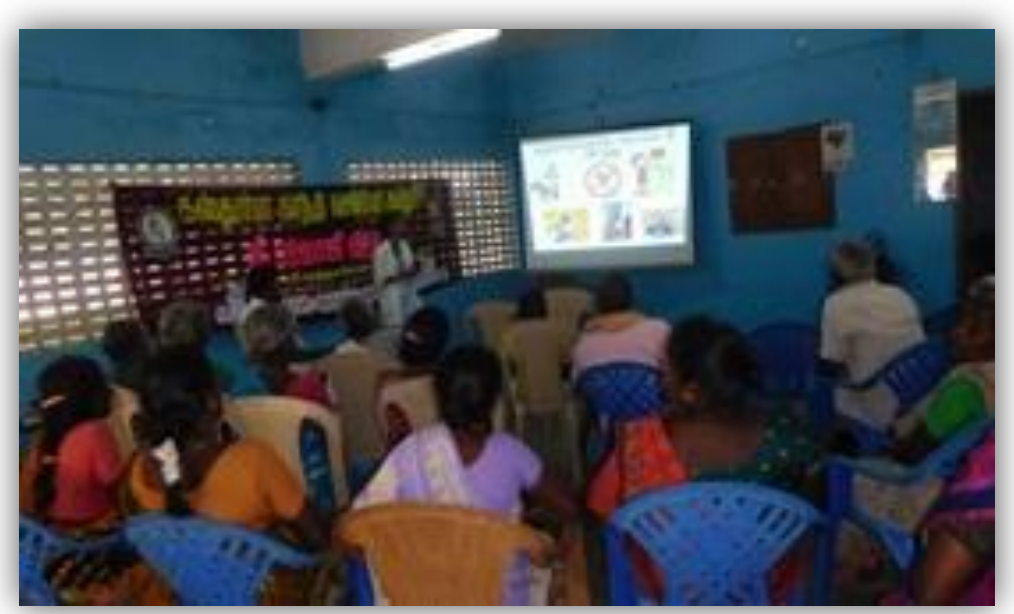

Department of
Medical Surgical
Nursing took a march
in front by organizing
an Instructive Video
Assisted Health Talk
among General Public
,Adingapattu on 28.02.
2017, Prevention of
Fire Accident and
First Aid Management
of Burns in

commemoration of National Burns Awareness Week . Ms. Nirmala, Tutor, Dept of Medical Surgical Nursing, sensitized the public about the Common causes of fire accident at house and community and first aid management of the burns wound until they reach nearest health care facility followed by the presentation, a video show emphasizing the value of precious time and prudent act during a fire accident were highlighted. In addition, information on how to prevent "Rescuer becoming a Victim" was also staged.

\section{SPORTS MEET Feb, 2017}

The Inauguration of sports meet-2017 was held on 23.02.2017.The inauguration commenced with college anthem at $3.30 \mathrm{pm}$, followed by welcome address delivered by Mrs. Jayanthi. K, Asst.Prof, SNA Advisor, KGNC .The first proceeding House robe \& capping ceremony for young Kasturbians of each houses was commenced by the Honorable Vice chancellor ,which was followed by Flag hoisting and March past by the students. The students from Respective Houses of Sapphire Blue, Amber Yellow, Emerald Green, Ruby Red, Amethyst Purple Zircon Brown showcased a perfect parade. Prof.K.R.Sethuraman\& Dr. Renuka.K Principal declared the Sports meet open by releasing the doves.The Inauguration proceeded with the next event of Lighting of Olympic Torch ignited by the dignitaries and 

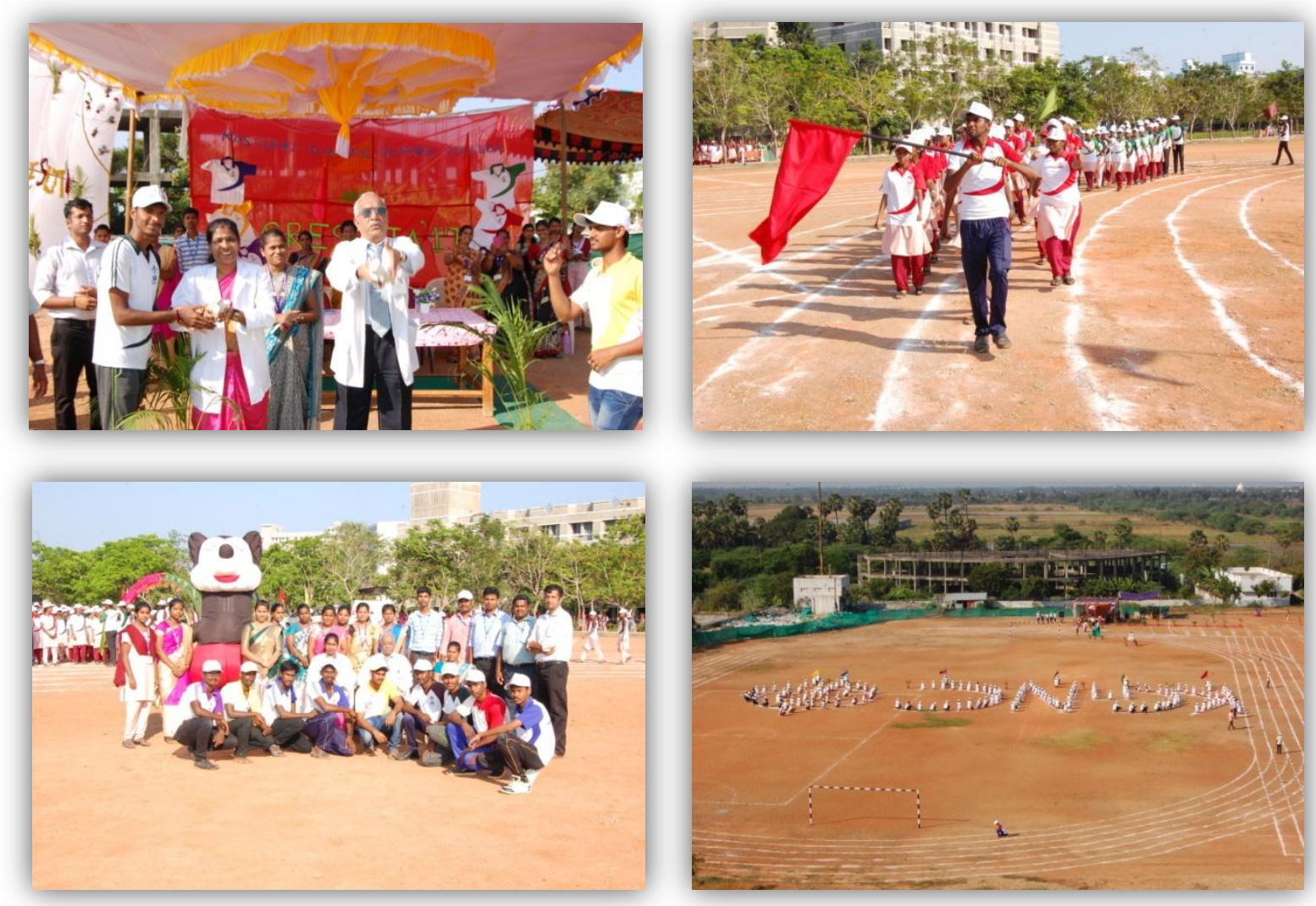

carried over by the Captains of 6 houses on to the torch Relay round the track. Prof.K.R.Sethuraman ,Vice -Chancellor, SBV addressed the gathering with his unique motivational speech. Ms.Nandhini.S, B.Sc(N) IV Year student ,SNA Secretary, rendered the vote of thanks. The day concluded with the National Anthem in Air. The sports events continued with various events for the next two days with full spirit and vigor.

\section{WORLD GLAUCOMA DAY Mar, 2017}

The Dept. of Medical Surgical Nursing took long leap in Commemorating the world Glaucoma day in union with NSS unit of Kasturba Gandhi Nursing College and the Dept. of ophthalmology at Mahatma Gandhi Medical college and research institute Pillaiyarkuppam, Puducherry in organizing the screening camp and health awareness

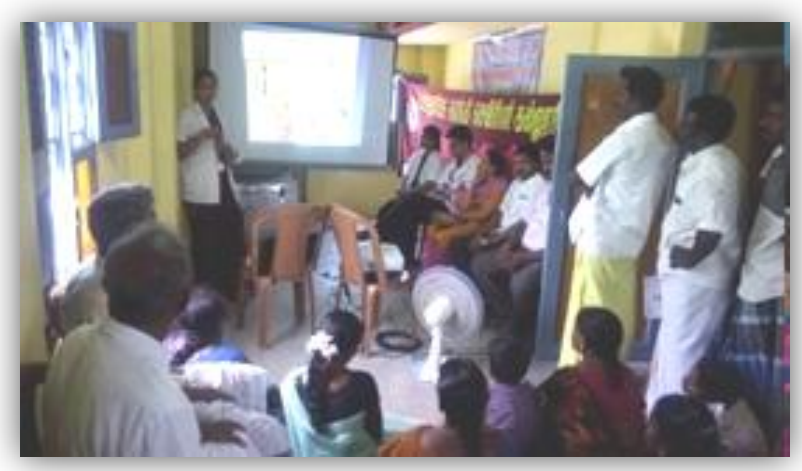

programme on world glaucoma day on 11.03.2017 at B. Mutlur. The program was inaugurated by Mr. Natarajan, Regional manager of Gramavidial Microfinancial LTD in B. Mutlur and the camp was conducted by Assoc. Prof. Dr. Swathi, Dr. Ashwinth, Dr. Vasanth department of ophthalmology at Mahatma Gandhi medical college and research institute, Mrs.Manopriya, Ms.Ponmani.c Faculty dept of Medical Surgical Nursing at Kasturba Gandhi Nursing College, Pillaiyarkuppam, Puducherry. Ms.Ponmani.c, Tutor, Kasturba Gandhi Nursing College gave a lucid health talk on "Glaucoma" followed by a video show. 


\section{CRESCITA - 2K17Mar, 2017}

The Annual Day cultural - CRESCITA 2K17 a colorful evening in the calendar of KGNC was held on 24.03.2017 in SBV ground adorned by a elegant stage of grandiosity and colorful air balloons. Mrs. Kripa Angeline A, Associate Professor, Dept. of Medical Surgical Nursing welcomed the gathering. Prof. K.R.Sethuraman, Vice Chancellor, SBV rendered his valuable presidential address. The CD of Sparklss'17, 5th issue Students magazine which was a perfect blend of skills, artistic talents and creativity of the students. The college annual report of 2016 2017 was deliberated by our Principal, a grand launch by the dignitaries on the Dias. Prof. P. Sumathy the chief editor gave a glimpse of the contents in SPARKLSS which was innovative.

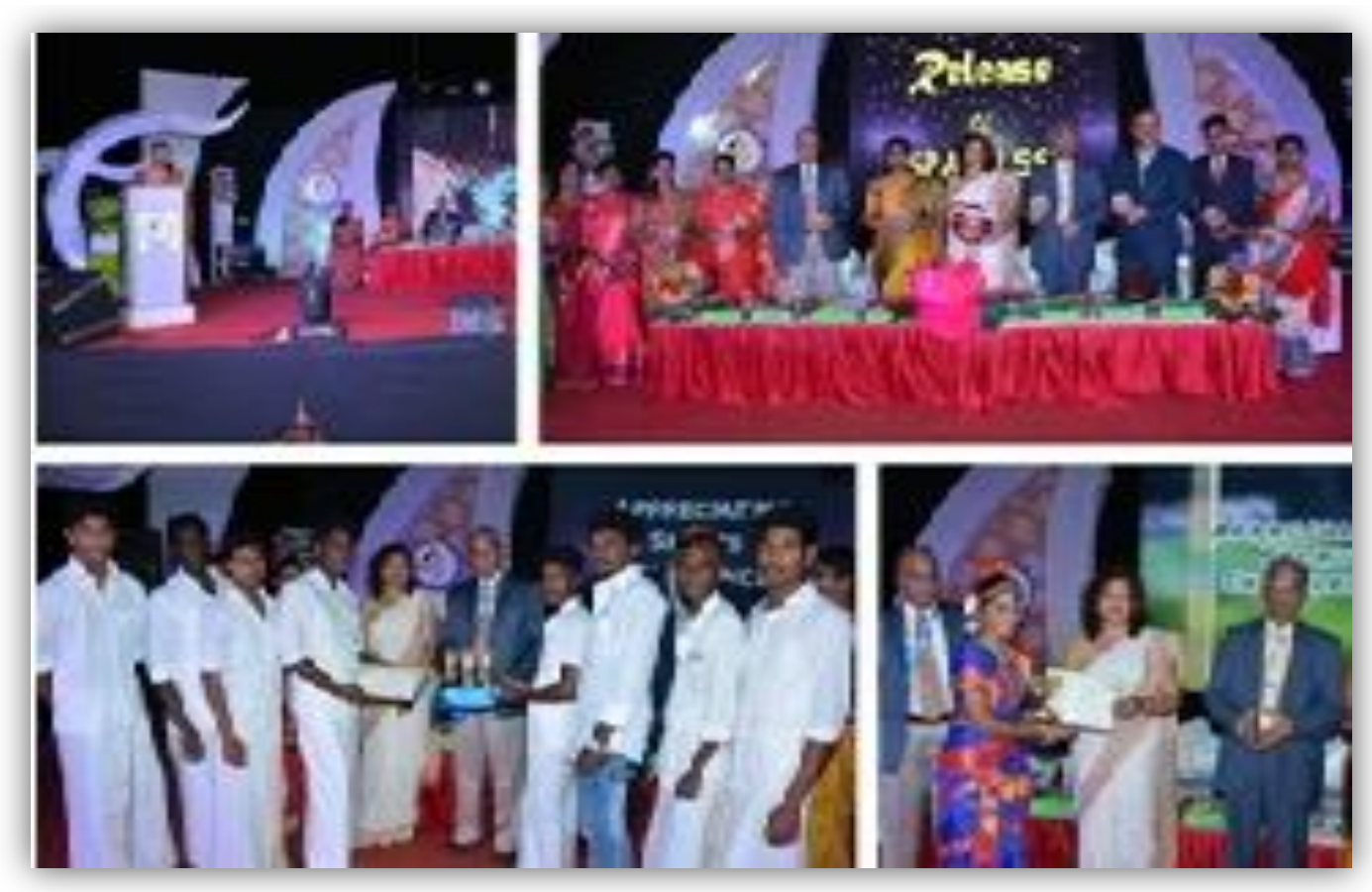

Dr.Renuka K, who highlighted the progress and milestones of KGNC which was noteworthy. With the motive of showcasing the talent of students in sports and extracurricular activities cultural, various competitions on fine arts, literary , sports \& culturals were conducted for the past two weeks. The winners of the events were honored on this day with a shield and certificate by the dignitaries. The prideful moment on stage was the bagging of overall trophy by redhouse bringing lot of cheers from the gathering.the untiring efforts of the students were evident by the joy seen on the faces of the students when the Ryzentronz recieved the trophy for organizing batch.

Prof. A.R. Srinivasan, Registrar, SBV and Prof. M. Ravishankar, Dean, MGMCRI felicitated the gathering. The chief guest of the day Dr. Daisy Saran, Managing Director, Daisy Hospitals, Chennai, in her chief guest address motivated the group on the values of life. The programme concluded with the Vote of thanks which was proposed by Prof. P. Sumathy, HOD, Dept. of Child Health Nursing, which was followed by the Cultural programme. The students staged entertaining, colorful, dazzling events which brought to limelight the Kasturbians creative and artistic talents.

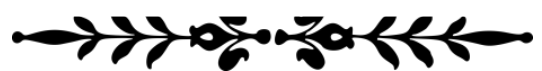

